\title{
CCC versus WWW: Digital Epistemology and Literary Text
}

\begin{abstract}
This chapter explores the concept of digital epistemology as a mode of thought. The digital is approached as a "lens" (Lindhé, Digital Humanities Quarterly, 7, nr 1. http://www.digitalhumanities.org/dhq/ $\mathrm{vol} / 7 / 1 / 000161 / 000161 . h t m l$. Accessed Apr 2020 (2013)), focused on the relation between cultural history, literary texts and digital discourse. Examining examples from different literary texts, from the 1960s to the 2000s, this chapter establishes a media archaeological juxtaposition between digital culture and early modern modes of thought such as the Kunstkammer, the emblem, the fragment, and also the archival principle of pertinence. The chapter argues that digital epistemology possesses a dual function: enhancing the reading of art and literature in the light of digital culture, and inviting a reconsideration-and even restoration-of the impact of early modern aesthetics.
\end{abstract}

\subsection{The Mechanical Hand}

In a remarkable piece of prose lyric from 1966, the Swedish author Göran Printz-Påhlson (1931-2006) lends his voice to Charles Babbage:

No man can add an inch to his height, says the Bible. Yet once I saw the detective Vidocq change his height by circa an inch and a half. It has always been my experience that one ought to maintain the greatest accuracy even in small things. 
No one has taught me more than my machine. I know that a law of nature is a miracle. When I see the dragonfly, I see its nymph contained in its glittering flight. How much more probable is it that any one law will prove to be invalid than it will prove to be sound. It must happen in the end: that wheels and levers move accurately but that the other number will appear, the unexpected, the incalculable, when the nymph bursts into a dragonfly. I see a hand in life, the unchanging hand of The Great Effacer.

Therefore, be scrupulous and guard your reason, in order that you may recognize the miracle when it occurs. I wrote to Tennyson that his information was incorrect when he sang 'Every minute dies a man, /Every minute one is born.' In fact, every minute one and one-sixteenth of a man is born. I refuse to abandon this one-sixteenth of a man. (Printz-Påhlson 201 1, 165, in Robert Achambeau's translation $)^{1}$

This reflection has a full title that almost makes for a piece of prose lyric in itself: "Sir Charles Babbage Returns to Trinity College after having commissioned the Swedish mechanic Scheutz to build a difference engine. On the bank of the River Cam he gazes at the Bridge of Sighs and contemplates the life of the dragonfly." Already the title, thus, seems to suggest some sort of information overload, if not in its content (the reader may have quite some use for this background) but in relation to common title practices. Moreover, the poem has as its subject a machine that produces other overloads-in the end "one-sixteenth of a man."

The Swedish original where this poem was published in 1966, Gradiva och andra dikter, has on its cover a photography of a mechanical hand, which at first glance looks like some form of prosthesis. The back cover explains that the photo is of "the mechanism in the hand of the 'musicienne,' the piano playing doll, which Henri-Louis Jaquet-Drotz displayed on an exhibition of automata in Paris 1783." Is this the hand of the poet? Poetry as an automated process? The Death of the Author?

The original collection is divided into four parts: the first one, in the form of a play, is a paraphrase on the German author Wilhelm Jensen's novella Gradiva from 1902 (which, obviously, has lent the poetry collection its name); part 2 contains poems about, among others, the Rosenberg couple accused of espionage, the (Swedish/Amercian) union martyr Joe Hill, Gustave de Beaumont and Alexis de Tocqueville, and the escape artist Houdini; part 4 is a short suite which under the headline "Summary"

\footnotetext{
${ }^{1}$ Printz-Påhlson's poems are translated by Robert Achambeau. I have taken the liberty of adding two commas in the above-quoted text. All other translations from Scandinavian languages are by me. See also Printz-Påhlson $(1966,57)$.
} 
contains three poems written in English about the comic characters Superman, Bringing Up Father and The Katzenjammer Kids. If this did indeed make up a "summary" it may be as a comment upon the metapoetic and cross-border character of the collection. The author comments in a footnote that "I have called Summary the section where I gather three poems in English about comic characters, in order to argue, for sure, that you don't have to be less serious when you write about Superman, Bringing Up Father or The Katzenjammer Kids, than when you write about the Rosenbergs" (Printz-Påhlson 1966, 69).

But it is part 3 of the book that is of particular interest to us, since here we find mechanical dolls, monsters and machines. The title of this section is "The Automata" ("Automaterna") and it contains six prose lyric texts, the first dedicated to the abovementioned French watchmaker and constructor of automata Jaquet-Drotz; thereafter a reflection in the words of Mary Shelley's "Man-Made Monster"; this is followed by a poem called "Formula Transition," inspired by the programming language Fortran; and the text quoted in the opening of this chapter is about Charles Babbage, the man behind the difference engine and the analytical engine, both considered pioneering steps towards the construction of the modern computer. The Automata section proceeds with a short text about the mechanical doll Olimpia (from E.T.A. Hoffmann's romantic novella The Sandman) and the suite ends with the poem "Turing Machine," where this theoretical construction is juxtaposed with "other kinds of machines ... more abstract automata, stolidly intrepid and inaccessible, eating their tape in mathematical formulae"(Printz-Påhlson 2011, 162; 1966, 59). But these machines, so the poem tells us, "imitate within the language"so maybe this, as the front cover photo, could be seen as another metaphor for the poet.

${ }^{2}$ At the end of the poem, the author lets the "monster" utter the following words:

For myself, it seems as if my background and construction limit the possibilities for the successful development of my personality in socially acceptable forms. Evidently, I must choose between two possible careers: either to seek self-expression in the pursuit of crime - within which vast and varied field of activity sexual murder ought to offer unsurpassed opportunities for a creature of my disposition - or during my remaining years quietly to warm my hands at the not altogether fantastically blazing but nonetheless never entirely extinguished fires of scholarship. (Printz-Påhlson 2011 , p. 166; 1966, pp. 54-55). 
What makes the Automata suite interesting is that it provides a concrete-and early (1966) - example of the representation of the digital in Swedish literature, while at the same time serving as a suitable gateway to the digital epistemology discussed in this volume. The representation of the digital is found explicitly in the Fortran poem, but indirectly also in the passages about Babbage and the Turing machine, since both of these names represent innovations and theoretical perspectives fundamental to the construction of the modern computer. However, the entire short section, which thus thematizes automata and other similar artifacts (such as Frankenstein's monster), can be seen as a manifestation of the more abstract, epistemological dimension examined in this book. Although the majority of the Automata texts do not explicitly deal with computers or digital technology, they nevertheless can clearly be seen as expressions of a discourse in which the digital marks its presence even when it is not articulated: Why write about Shelley, Babbage and eighteenth-century automata in 1966? Or, for that matter, why do poetry of cartoon comics? The latter could, of course, be related to the enthusiastic reception of pop art in the 1960s (Warhol, Lichtenstein, Fahlström, etc.), but also-or precisely because of this - be seen as a perspective shift away from the book's hegemonic status as a literary communicator, to a more complex cultural discourse, where media, technical artifacts and popular expressions occupy the same position as "the sunset" and "the sea." 3

Let us now move forward, to the Swedish 1990s.

\subsection{The Literary Text: Operation CCC}

The heading of this chapter may seem a little enigmatic. Here is an explanation:

3 "The poem about the beautiful sunset has run into some problems," wrote the Danish critic Staffan Hejlskov Larsen $(1971,172)$. Maybe he was thinking of the Swedish poet Göran Palm, who in 1964 made a sensation with his poem "Havet" ("The Sea"). In a free English translation:

I stand in front of the sea.

There it is.

There is the sea.

I look at it.

The Sea. Well.

It's like at the Louvre. (Palm 1964) 
When the three books were written I did have a computer, but my search for information did not go through search engines, googling or by any other ether devices. No http://www. WorldWideWeb - but rather http: //ccc. CarCargoCollections. ${ }^{4}$ The body instead of the ether. I am not saying this to heroize an older, more artisan mode of production, but to give a reasonable historical record. And to cast a suspicion that the way of writing or the choice of mediation already was inherent in the air I was breathing, that others had already begun with something I did not know of (but still somehow was affected by). (Gunnar D. Hansson 2009)

The quote comes from a lecture in 2008 by the Swedish author and professor in comparative literature Gunnar D. Hansson. In the 1990s he had written a number of books, Olunn, Lunnebok and Idegransöarna, dealing with (in turn) mackerels, puffins and yews. By the year 2008 these books were released in a compilation volume (Hansson 2008), and that was the reason for Hansson's reflection, which may serve as some kind of poetics in reverse.

These books are remarkable in many ways, not least in their structure. Since Hansson was an established poet, the titles ended up in the poetry section of bookstores, but they could just as well have been categorized as prose, documentary literature, folklore research, sagas, encyclopedias, travelogues and so on. Around the topic of each volume, the author presents poems, essays, prose, facts, tales, tables and speculations, but all this in the complete absence of summary syntheses, conclusions or overall reasoning. How do you summarize a mackerel, anyway? Or, as British botanist Alan Mitchell says, speaking about the yew: "There is no theoretical end to this tree, no need for it to die" (Hansson 2009). Clearly, there is something unsorted and encyclopedic about these texts. They become archives, but hardly sorted according to the post-romantic principle of provenance-by cause and origin, that is - but rather by the more associative order we stumbled upon in previous chapters: the principle of pertinence-to which we will return soon.

So, we look for expressions of a "digital epistemology" and find it in a formal order, or "disorder," in books about mackerels, puffins and yews. In the case of the trilogy, the author himself suggests that there was something outside his own conscious creation which influenced the arranging of his texts, "something I did not know of (but still somehow was affected by)." What his self-insight confirms is that what he envisioned in the early 1990s was not intentionally related to digital technology, but that he is aware that

\footnotetext{
${ }^{4}$ Originally it read "http://BBB:BilBåtBibliotek," which stands for car, boat and library.
} 
his books in their very form and structure nevertheless came to embody some of the characteristics of the new media (that Gunnar D. Hansson by that time had translated, and introduced to the Swedish public, Walter J. Ong's Orality \& Literacy may have helped his self-observation).

There are, of course, more examples. In the "CCC era" Swedish author Gabriella Håkansson published her debut novel, the sequential story Operation B (from 1997, with a digital sequel published on the Bonnier website as Operation SnabelBeta - "snabel-a" being the Swedish word for the "at" sign, the title would translate to something like "Operation Bat Sign"). ${ }^{5}$ The first part of the novel describes a woman who has been married to a man for several decades, before she finally-and as part of an ongoing research project-simply kills him, since the investigation is over. The notion of reckless science, which in this way brutally affects people's lives, constitutes a stark contrast to the 1990s' most radical postmodern notions that "everything" is "text." At the same time, Håkansson's novel is largely playing with the notions of text and narrative.

It is, indeed, an obscure "Operation" that holds the novel's fragments together. A conspiracy? Or simply the conditions for power? Or an allegory about the task of writing novels when the great Narrative no longer has an end-“the end of history?" In Håkansson's case, moreover, the absence of an end became literal when new sequences were published on the internet, in what may have been the first network-based work in Sweden published by an established publisher (Bonnier). One of these "digital sequences" relates a slideshow (yet another obsolete technology) presented by a psychiatrist. The case she presents is about a man who has become obsessed with repairing the sewer at his summer cottage, and as a result has lost his family - and his sanity. The therapy suggested is to build small models of the living room where the pipe system is actually finished, after which the man is allowed to build a slightly larger model, and so on to more and more models, the last of which is at a natural size. The treatment method is described as a success. But what happens when the representation can no longer be separated from "reality," the original? Is it the reality that is lost—or is it the representation? Will fiction disappear, or will we (as did many in the 1990s) rather argue that everything consists of stories? Of text? Gabriella Håkansson's 1990s were greatly influenced by these issues - we saw it in Cultural Studies insisting that "everything" is a story, and in the pedagogs' ever-expanding notion of text and of course the oft-cited, and misunderstood, Derridean phrase il n'y as pas de

\footnotetext{
${ }^{5}$ The link to Operation SnabelBeta was, unfortunately, broken long ago.
} 
hors-texte. The story of the summer cottage does not differ from the summer cottage. The research project does not differ from life.

From a digital perspective, can we perhaps turn the problem upsidedown and ask ourselves if instead it is our representations that are always already reality? This, of course, may be considered an epistemological fact, but our digital habits further emphasize this-the representations we create are constantly ongoing. The original concept of mimesis also included methexis, participation (Sypher 1968, xviii; Kelty 2016). An imitation was not primarily a representation, it meant performing something, a participation, just as in many of today's digital forms of expression; and also in the rudimentary interactive text that Operation SnabelBeta resulted in. ${ }^{6}$

To summarize this far, by reading through the looking glass of digital epistemology, we can detect traces of digital order, and digital structures, in texts that do not explicitly deal with computer technology, but rather display themes and orders that can be productively related to their digital environments.

\subsection{Postdigitality and Analog Nostalgia}

The fact that the digital "exists everywhere" has its origin in the observation that our environment is built on "code" rather than "codex" (although these are not binary concepts, since most codices today rely on code). This generates notions - and staging - of our entire existence as actually translatable and reproducible. As Rasmus Fleischer points out in his Det postdigitala manifestet ("The Postdigital Manifesto"), the only thing that keeps the music alive is the copying; that is, reproduction. Each listen to a CD or a downloaded file actually creates a new copy at the moment of playback (Fleischer 2009, 53)..$^{7}$ The boundary between copy and original is challenged, a fact that leading market forces, for obvious reasons, resist by all

\footnotetext{
${ }^{6}$ Gabriella Håkansson has told that she had big plans, and got some pledges from the publisher, regarding her digital sequel. Gradually the publisher curbed its enthusiasm, and in the end there remained some clickable chapters, a rudimentary hypertext (private conversation).

${ }^{7}$ The full quote reads:
}

All use of digital information means that the information is deleted. If a computer program fails to erase the tracks, the computer hangs up and in the worst case has to be restarted. All digital files will be deleted sooner or later. This is too staggering to think about in one's everyday interactions with computers. ... A digital file cannot be made permanent except by incessant copying. Without being copied further, it is impossible for a digital file to survive even half as long as an old gramophone record. 
means possible. But this insight also makes us aware-or makes us suspectthat our own identities are not that original, either. William S. Burroughs' experiment with tape recorders in the 1960s, and the conclusion that we all, our speech, our bodies, are always already pre-recorded, looks uncomfortably prophetic (Burroughs 1962). Try to say something new at a party, something you never said before. If, in the 1960s, this could be received as a striking but nonetheless curious observation, the same statement in our own - posthumanist, digital — era becomes an existential reality.

The observation of these phenomena has given rise to the "postdigital" condition that inspired Fleischer's manifesto. That being said, it is important to realize that this is not to be confused with an "anti-digital" attitude, nor a notion of something to surface "after" the digital. Rather, the notion of the postdigital expresses an awareness that digitization has created certain phenomena and artifacts which cannot easily be incorporated into the traditional capitalist logic that is often regarded as associated with digital culture (as long as it does not threaten its own interests). It is also about letting us understand that the digital cannot be realized without analog receptors in the form of text, sound, light and so on; this is the starting point for an analysis of the complex and-as we observed in Chap. l-non-binary relationship between digital and analog culture.

One expression of a postdigital approach to cultural production is what has come to be called "analog nostalgia," which was mentioned in the previous chapter. The concept of analog nostalgia has been attributed to Laura Marks and was launched around 2000. In the essay "Analogue Nostalgia and the Aesthetics of Remediation" from 2014, Dominik Schrey parallels the phenomenon with the ruin cult and fragment aesthetics of the eighteenth and nineteenth centuries (Schrey 2014; see also Marks 2002). ${ }^{8}$ In a prolongation of Marks, Schrey claims that analog nostalgia is partly that digital technology is used to emphasize the analog, and partly that it is the "noise" rather than the "signal" that is noticed:

[T] he phenomenon is not about the refusal of digital technologies, but exclusively about the digital remediation of analogue aesthetics within the

\footnotetext{
${ }^{8}$ Ruin romanticism and fragment aesthetics, albeit not early modern, are two highly interesting art historical concepts in the light of digital epistemology. Moreover, it has to be said that early modernity is not an end in itself here; rather, it is the recursive (see Chap. 1) oscillation between different historical moments and genres that is in focus. It will be interesting, in coming projects, to further explore both these romantic phenomena as well as premodern forms and classic rhetoric through the digital lens.
} 
digital. To put it in terms of communication theory, analogue nostalgia is directed towards the noise, not the signal. In the broadest sense, it operates as a strategy of re-enchanting an object through aesthetic defamiliarisation [sic] as it is characterised by deliberate imperfection. (Schrey 2014, 34)

Of course, it is in this "noisy soundscape" that we also identify the rattle of the machine, relive the shortcomings of Dolby B, feel the weight of the book and connect the vinyl player through Bluetooth or the computer's USB port. Analog nostalgia, thus, is one of the most concrete expressions of media materiality observed through digital epistemology.

Examples of this materiality from our own twenty-first century can be found in the Swedish poet Johan Jönsson's astonishingly extensive collection of poems, which must almost be described in terms of a postdigital and poetic epistemology: Mot, vidare, mot (2014, "Towards, further, towards") counts 1562 pages and med.bort.in. (2012, "with.away.with.") counts 1244 pages (Jönsson 2012, 2014). Another expression of this materiality is Swedish journal OEI's monumental relation to paper consumption, publishing issues that are so dense as to almost oppose distribution. ${ }^{9}$ Whether or not these works are produced with "the digital" in mind, their mere presence among pdf files, smartphones, websites and snapchats makes for a brutal statement that definitely differs from how the same products would have been perceived 50 years earlier. Through their manifest materialities these expressions establish media archaeological access points where concepts such as "digital" and "analog" can be further problematized. ${ }^{10}$

Former Swedish Academy member Lotta Lotass is another writer who stubbornly drives an analog nostalgic campaign. Her neo-modernist approach of presenting literary fiction in a box of pamphlets, as in Den vita jorden ("The White Soil" or "The White Earth", 2007), or as a 50-meterlong telegram strip containing one single sentence, as in Fjärrskrift ("Teleprints" 2011), is a tangible expression of a postdigital discourse. It is notable that many of Lotass' texts contain a lot of technology (many explorers, many technological advances), but digital technology is mostly absent on the explicit level of the texts. However, it is not a case of Lotass

\footnotetext{
${ }^{9}$ For example, OEI \#53-54, "Dokument, Dispositiv, Deskription, Diskurs," counts 1280 pages, while OEI \#63-64, "Strata, geologisk tid, jordkonst/Land art i Sverige," counts a humble 688 pages. It has happened more than once that the editors have asked subscribers to collect the journal at the office, since they are too expensive to send by mail.

${ }^{10} \mathrm{On}$ the relation between analog and digital, see the introductory Chap. 1.
} 
creating these works to "challenge," "resist" or even "relate to" her digital contemporary-digital epistemology establishes its own relationships (moreover, Lotass has created digital works as well). What seems to characterize Lotass' prose, however, is the almost demonstrative lack of networks. Sometimes (like in Den vita jorden) it seems that the text itself lacks a common network. Make it a box instead.

\subsection{Digital. Tactile. Cabinet}

(DO NOT touch the objects

The surface absorbs

salt, dirt and fat.

Do not touch.

The acids of the skin

causes oxidation.):

$\ldots$

These lines are translated from the Finland Swedish poet Ralf Andtbacka's (2008) collection of poetry Wunderkammer (Andtbacka 2008, 18). This poem-probably an objet trouvé, and as such possibly a note from a museum somewhere-establishes a paradox. Twice, the reader is prompted not to touch the objects. But by this very gesture-the injunction not to touch - a tactile dimension is established in these brief lines. "We will not ever come closer, and yet more distant, to the thing-in-itself," as Swedish critic Mattias Pirholt notes in a review (Pirholt 2010). It is an observation of tactility that is enhanced by the information about our fingers, as index and digit (Peters 2016). Fingers (index, digit) are not only digital, but also contain salt, dirt and fat, and they carry acid which may cause oxidation. The human touch is a chemical laboratory.

In Wunderkammer one finds several reflections on humanity's relation to the objects around us. The motto of the book reads (in Swedish): "There is something odd about things. /How they gather, and silent stay; /how they disperse, if you may." It is poetry that almost could be a textbook example of actor-network theory-the objects are indeed agents in Andtbacka's poetry. ${ }^{11}$ And these objects are constantly engaged in new

${ }^{11}$ Actor-network theory (ANT) is a way of describing our relationship to objects that are not normally attributed agency. For an account of some of the theory's trends, see Latour (2005). In an article explaining some of the theory's premises, Latour (1996) argues: 
relationships, not only in language (this is more than language poetry), but rather in the very relation of things to each other, to language, to human beings, to life. Neither are the digital objects excluded-primarily they mark their presence through the playful, neo-modernist typography. But as we shall see, there are also media archaeological points of contact between a digital epistemology and the aesthetics based on the Wunderkammer that gave the poetry collection its name.

I have already described some basic characteristics of the cabinet of curiosities in Chap. 1. With Horst Bredekamp-and Francis Bacon-the playfulness of the Kunstkammer was emphasized (Bredekamp 1995, 67). In Ralf Andtbacka's Wunderkammer, tooCabinets of curiosities, the poetic structure is maintained by this playful materiality-digital as well as tactile-and by negotiating the relation between sorting and association. Andtbacka's collection of poems refers not only through the title, but also in its practice, typographically, thematically and ironically (Malmio 2020), to the cabinet of curiosities as an order of knowledge. But this is also put in relation to digital technology as a system of information management.

It is thus rewarding to read Andtbacka's book in the light of the associative logic of the Kunstkammer, but also as an expression of a digital epistemology and, further, to see the Kunstkammer's mode of thought as a congenial expression of this epistemology. As for the expressions of digital technology in Andtbacka's text (Fig. 3.1), they are most evident through the book's typographical playfulness, but also through a list, at the end, of (for the book's research) relevant web pages, sorted in the form of an hourglass and with the supplementary invitation to "record the date when you discover that all the verses in the poem are dead" (Andtbacka 2008, 147, my italics). The poet's insistence that the prosaic internet addresses are "verses" in a "poem" establishes another relationship between art and digital culture, and between "life" and "death": a URL or, rather, a verse that can "die" must have had a life.

AT [Latour's abbreviation for ANT] has been developed by students of science and technology and their claim is that it is utterly impossible to understand what holds society together without reinjecting in its fabric the facts manufactured by natural and social sciences and the artefacts designed by engineers. As a second approximation, AT is thus the claim that the only way to achieve this reinjection of things into our understanding of the social fabric is through a network-like ontology and social theory. 


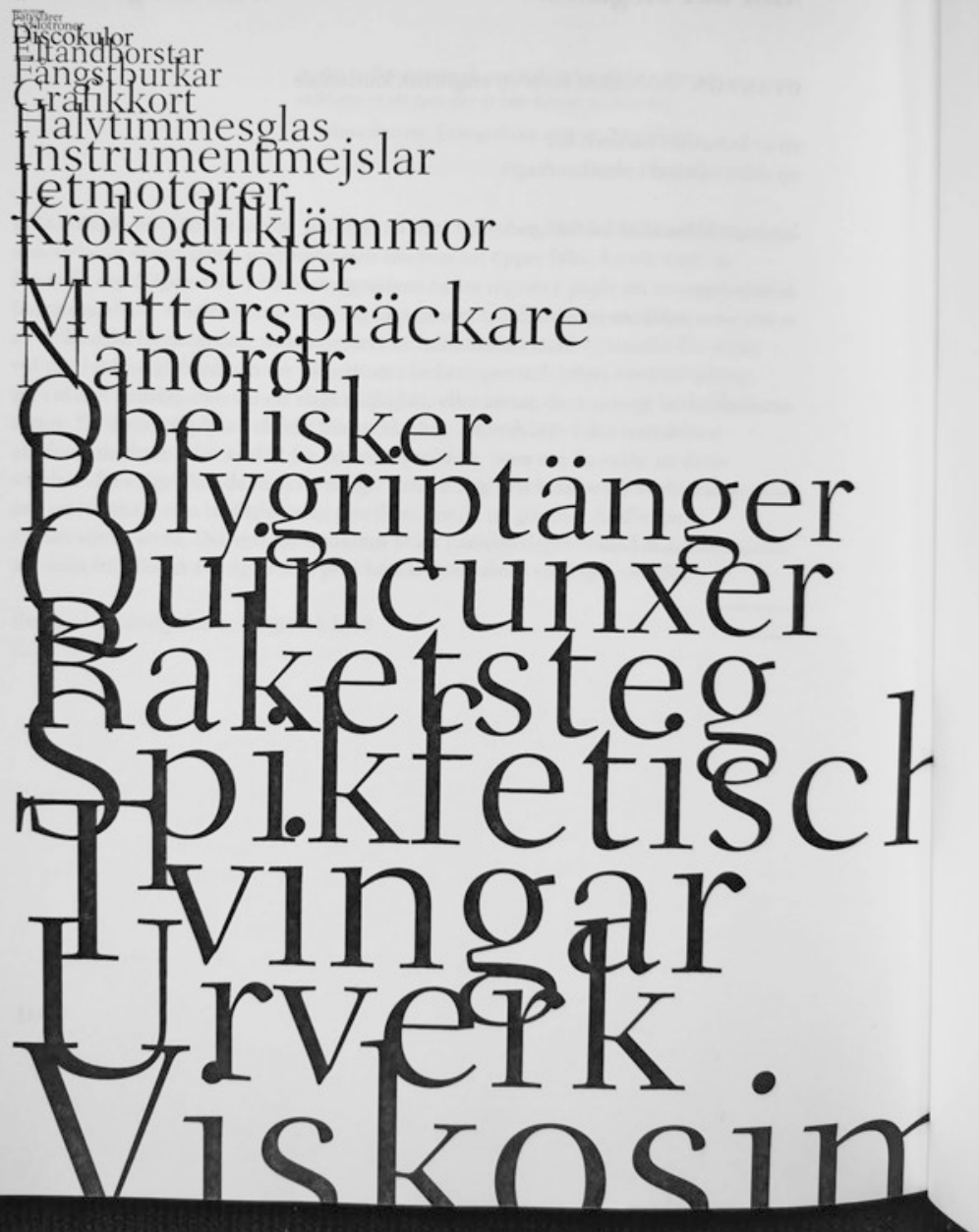

Fig. 3.1 Ralf Andtbacka (From Wunderkammer 2008, photograph) 
One of the poems in Wunderkammer carries the title "Naturalia \& artificialia," and thus directly addresses two sorting principles of the cabinets (the other two, according to Bredekamp, being Scientifica and Exotica; see Chap. 1, and Bredekamp 1995, 34). The poem begins with a classification of a plant, written according to the order established by Carl von Linné: Name; Class; Order; Family; and Place of Growth. Interestingly enough, Horst Bredekamp points out that precisely Linnaeus's sexual system is one of the clearest examples of the new modern order that entered at the same time as the status of cabinets of curiosities started to decline (Bredekamp 1995, 88-91). Enter modernity. Thus, the first lines of the poem juxtapose-consciously or not-two contradictory systems of knowledge: the associative practice of the Kunstkammer and the systematic logic of Linné. ${ }^{12}$

Returning to the introductory quote from Andtbacka's book, we see a typographic peculiarity that recurs in the first half of the book::...A colon followed by an ellipsis (and throughout the book these ellipses are repeated). The colon suggests a following paragraph or sentence, often with some informational content. Also, the ellipsis suggests something to be continued. With this tiny typographic detail, the poet fuses disparate elements "in free, concomitant phenomena void of obvious purpose" (again, Bredekamp 1995, 109), whether the reader accepts this or not. Andtbacka thus locates the cabinet to language itself: not only to language but also to typography and-finally - to digital technology. Nevertheless, as previously pointed out, this is not a laboratory for language poets only. The materiality of the Wunderkammer is tactile, and epistemological.

\subsection{The Principle of Pertinence}

The organizational principle of the cabinet of curiosities, and Andtbacka's book, once again lead us to one of the observations we made in Chap. 2, and of Gunnar D. Hansson's poetics, namely the principle of pertinence. The principle of pertinence (and, consequently, also the Kunstkammer) can be seen as an attempt to maintain a divine order, a model of the

\footnotetext{
${ }^{12}$ This collision of epistemic systems is similar to the observation made by Norbert Wiener, in the introduction to his groundbreaking work Cybernetics: or Control and Communication in the Animal and the Machine (1948). In the opening pages Wiener actually analyzes a German nursery rhyme, which mentions clouds and stars, and he observes that this little song actually combines two different epistemes: astronomy and meteorology (Wiener $1948,30)$.
} 
world. ${ }^{13}$ The principle of provenance, on the other hand, transforms the archive from a "message" into a resource for these models. As already noted, Susan A. Crane, in her essay about cabinets of curiosities and the Museum of Jurassic Technology, describe the objects in the Kunstkammer as telling stories, blending fact and fiction: "[T] he desirability of the curious object lay in its relation to a known or acceptable story" (Crane 2000, 72). The objects in the museum, on the other hand, should be seen as representations, as part of the great national mythmaking: "[T]he historical object participated in a narrative uniting location and experience" (ibid., 76). The archive ordered by provenance, arranged by source and origin, also tells a story about the archive's own creation, a story that differs significantly from those told by the principle of pertinence.

This principle-also, we may remind ourselves, known as the subject principle or the dossier system-coincides with Horst Bredekamp's description of the cabinets' mode of thought: the true expression of an object or a person is discovered in freely associated phenomena, with no obvious connection. In the essay written for Litteraturbanken 2017 (see Chap. 1), Andreas Önnerfors also argues for the connection between cabinets of curiosities and the principle of pertinence:

The digital softens up staggered epochs and makes the texts of the past immediately present, with a potentially acute contemporary relevance. In the digital Wunderkammer, knowledge can be formed through a creative combination of different approaches, which challenges our classic notions of the relationship between text and context. Furthermore, I argued that the digitalisation of the searchable whole of the text also dissolves the classical hegemony of earlier knowledge organizations. (Önnerfors 2017)

Moreover, these tendencies coincide with several of the approaches within the emerging field of media archaeology, and this becomes even clearer by considering the synonyms for English's "pertinence" that The Merriam-Webster Dictionary lists: applicability, bearing, connection, materiality, relevance-all of which seem to be relevant to the media archaeological discourse. ${ }^{14}$ Not only Google but also many pre- and early modern forms of thought harmonize with this way of arranging and commenting

${ }^{13}$ Pointed out by Otto Fischer, professor of rhetoric at Uppsala University, private conversation.

${ }^{14}$ See the Merriam-Webster online entry for "pertinence", https://www.merriam-webster. com/dictionary/pertinence (accessed May 2020). 
on existence. The recursive move from provenance to pertinence thus becomes a key to the description of a digital epistemology. In light of the principle of pertinence, we can return to texts such as Lotta Lotass' Aerodynamiska Tal ("Aerodynamic Figures") from 2001, a catalog of famous aircraft sorted by the years they appear in history (Lotass 2001). Also, Gunnar D. Hansson's AB Neandertal (1996, "Neandertal Inc."), builds on the associative principles of the previously mentioned trilogy, but this time the text is arranged alphabetically. Already the title can be read as a compressed "list" which simultaneously marks a beginning and an end: $A B$, as in the alphabet. Neanderthal, the extinct archaic human species.

The relationship between pertinence, cabinets of curiosities and media archaeology is further strengthened by the fact that it was the Enlightenment and systematic ordering of progressing Modernity that brought an end to the organizational principle of the Kunstkammer. Patrick Mauriès writes in Cabinets of Curiosities how the escalating interest in optics and telescopes in the eighteenth century was viewed with skepticism among collectors of curiosities, as these tools were devoted to the study of the particular and the individual object, rather than letting the viewer marvel at the irregularities of creation (Mauriès 2015, 182). ${ }^{15}$ The classic cabinet encouraged combinations, the crossing of borders and the affirmation of similarities between nature and culture, artifact and organic, the grotesque and the beautiful. The cabinets that materialized in the nineteenth century with few exceptions exhibit a museum order, where provenance and science are prevailing principles. It is the organizational, and by reason structured, order of modernity that has made its entry:

The cult of curiosities was a cult of summation, of the sum total of things, of juxtaposition and addition repeated ad infinitum; the Age of Enlightenment, to reiterate a contrast that is now time-honoured, adopted a stance at the opposite extreme, placing itself firmly on the side of universality, of a hierarchal world view, and of an assumption of the validity of the

${ }^{15}$ Patrick Mauriès 2015 (2002), p. 182:

If he [Emanuele Tesauro] took as his title for his most celebrated work The Aristotelian Telescope (Il Cannochiale aristotelico, Turn, 1675), it was in order - significantly - to lament the fact that the telescope diminished the mystery of creation. 
broader categories of reason. [footnote in quotation] After 1750, the collector of curiosities and "patient pedant," as represented by Sir Thomas Browne, was to give way to the Encyclopaedists, who dismissed the naivety and archaic approach of their predecessors with withering scorn ... (ibid., 189) ${ }^{16}$

Media archaeology adopts Foucault's (and several other postmodern thinkers') criticism of modernity's trust in reason. Through mediahistorical juxtapositions, archaeological "finds" and alternative historiographical strategies, modernity appears more or less as a parenthesis, a way of arranging culture and science that has certainly been educational and systematically satisfying, but at the same time exclusive, elitist and not the least arbitrary. This is echoed in a fine formulation by Rasmus Fleischer in his Det postdigitala manifestet:

Between the pre-modern and the post-digital, we find, as if folded-in, the whole package that is usually called modernity. A systematic division of such things as body and soul, nature and culture, object and subject, were its characteristics. At the end of the eighteenth century, "culture" was invented as its own sphere, defined as a counterpart to the sphere of industrial production. (Fleischer 2009, 26)

Digital works, so far, are absent in this presentation — but only to clarify that digital epistemology is not necessarily a matter of digital objects. An important ambition with the concept of digital epistemology, however, is to abolish the sometimes still quite sharp distinction between on the one hand digital born, electronic works and on the other hand traditional book culture-or other media, for that matter.

The present text should therefore be regarded as a sketch, as another attempt (I mentioned a few in the first chapter) to put "the digital" in a new light and to connect the (post)digital with early modern culture. As we have seen, media archaeology as a concept shares many of the principles that can be found in some early modern modes of thought, as well as in many of today's digital expressions. Search engines and digital interfaces (in telephones, tablets and computers) as well as electronic works,

${ }^{16}$ The footnote in the quote refers to Guiseppi Olmi, "Théâtres du monde, les collections européennes des XVIe et XVII siècles," in Roland Schaer (ed.), Tous les savoirs du monde: encyclopédies et bibliothèques, de Sumer au XXIe siècle, Paris: Bibliothèque Nationale de France 1996. 
computer games and memes exhibit multimodal expressions that expose many similarities to early modern forms. The search engine and the computer desktop are not limited to genres but to function, and they re-examine relationships between cause and effect, materiality and distance, provenance and pertinence. Electronic literature, games and memes blend texts, images and sounds into a multimodal experience that has more in common with the cabinet of curiosities, the emblem and fragment aesthetics than with linear narratives, provenance principles and strict categorizations.

\subsection{Imri Sandström: Language and the Principle of Pertinence}

The Swedish artist and author Imri Sandström's “text box" Det kommande skallet/The Coming Shall, from 2017, in this context is an example of both analog nostalgia and (post)digital remediation. Her work also displays features we could describe as a "principle of pertinence of language." 17 By various stagings, Sandström's work establishes an interaction between text and image that, through its activist approach, its enargeia, in Cecilia Lindhé's words could be called "ekphrastic"; that is, directed speech that calls for the reader's (or listener's) own creation of images, the viewer's own activity (Sandström 2017; Lindhé 2013).

Sandström works in a variety of formats, such as text in book form, installations, performances, visual and digital art. In 2019 she finished her PhD project in Literary Composition at the University of Gothenburg, with the title Tvärsöver otysta tider/Across Unquiet Times (Sandström 2019). In dialog with, among others, the American critic and poet Susan Howe, Sandström in this project mainly focused on installing a number of relations between the history of the Västerbotten region in Sweden and New England, USA. She does this partly through juxtapositions of both these regions, inspired by postcolonial theory as well as by Bakhtin's concept of the chronotope (Bakhtin 1981), but also by bold transformation maneuvers such as various different "counterintuitive" translations with homonymous practices and puns. Thus, Bakhtin's “Chronotope” becomes

\footnotetext{
${ }^{17}$ In Kungliga Biblioteket (the Swedish Royal Library) the arrangement of files in accordance with the principle of pertinence was called "the dossier system," which seems appropriate in this case, since Sandström's work, the text box, indeed could be seen as a dossier. Again thanks to Otto Fischer for this information, unpublished conversation.
} 
"Kronotorp" (a small Swedish croft, instituted by the state for colonizing the North), where the notions of time and space in the literary text transform into a postcolonial discourse about the state's desire to control northern labor in the first half of the twentieth century (Sandström 2017, 35-38). Another example of how Sandström plays with homonymous juxtapositions can look like this:

I översätts till svenskans in. The Swedish word i means in.

I skogen In the woods

I skogen I the woods

$[---]$

The English I is pronounced AJ

Jag, I uttalat aj in Swedish

this is an expression of pain:

"AJ, det gör ont!"

"I, it hurts!". (Ibid.)

Sandström's project in this text box-or dossier-embraces several of the aspects that the perspective of digital epistemology brings forth. The very act of publishing texts in a box confirms previously noted strategies for establishing paper and print culture's tactility in our digitized and screen-mediated existence (we have mentioned Lotta Lotass' Den vita jorden, Johan Jönsson's poetry collections, the monumental editions of the magazine $O E I$ ). Moreover, the content of these dozens of small text booklets in turn remediates digital installations that have either been presented as installation performances or published on the author's website (or both).

It is thus a seemingly loosely connected work, characterized by both analog nostalgia and tactility, as well as reuse and reconfiguration of digital installations. "Seemingly," that is, because the project has some very clear nodes. One node is represented by the before-mentioned geographical juxtaposition of New England and Västerbotten, and thereby a "monological" dialog between Susan Howe and Imri Sandström ("monological," since this dialog takes place on Sandström's terms and with well-chosen reuse of text passages by Howe); another node is linguistic labs with homonyms, direct translations and puns (Chronotope/ Kronotorp; I/AJ), which in repetitive practices twine the work together. 
Sandström's box presents the title and subheading on both sides, in Swedish and English respectively. The full name of the work in English thus reads:

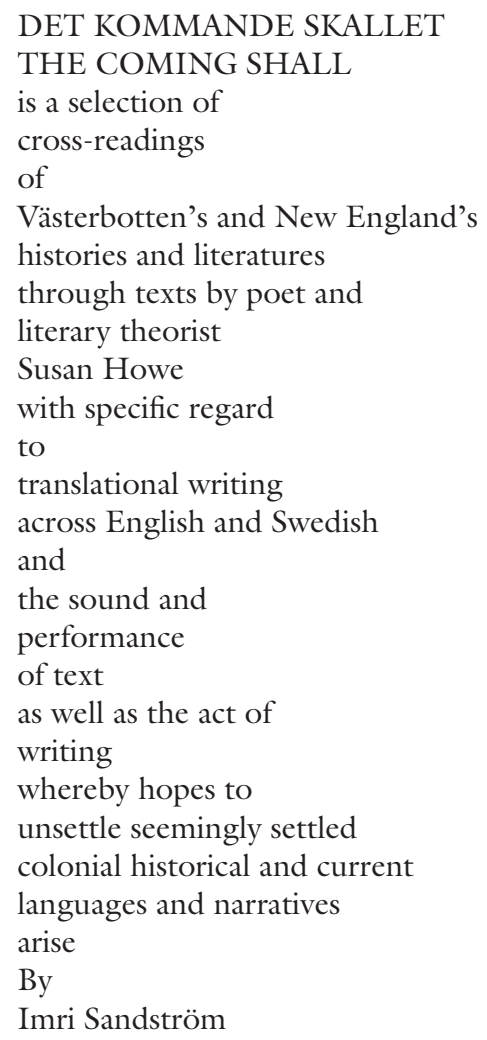

This extensive, almost archaic title/subtitle (the thoughts go to the elaborate subtitles of early seventeenth- and eighteenth-century novels) also suggests what the reader of these small booklets can expect. ${ }^{18}$ Text

\footnotetext{
${ }^{18}$ See for example the first edition of Daniel Defoe's Robinson Crusoe: THE LIFE AND STRANGE SURPRISING ADVENTURES OF ROBINSON CRUSOE, OF YORK, MAR INER: Who lived Eight and Twenty years, all alone in an uninhabited Island on the Coast of AMERICA, near the mouth of the Great River of OROONOQUE; Having been cast on Shore by Shipwreck, all the Men perished but himself. WITH An Account how he was last strangely delivered by PYRATES. Written by Himself. LONDON: Printed for W. TAYLOR at the Ship
} 
becomes sound in the various translation acts; the reader is tempted (or sometimes almost forced) to read aloud. But also, the visual installations of the texts (where a fragment from the Pietist theologian Cotton Mather can be enlarged into absurdum until only cloudy pixels are visible) challenges the normal relationship between language and materiality. Swedish blogger and literary critic Bernur (Björn Kohlström) identified this as follows:

Writing about writing: this is a performative act, which focuses on the linguistic. Sandström also utilizes the book page, where English and Swedish can run quadruply, but sometimes also left untranslated, or part of an exchange between the untranslatable, where "yet another deviant" becomes "ännu en eljest," without your reacting to something happening in the translation. It is a creative language game performed here. And, as a result, a linguistic leak occurs. (Bernur 2018)

This "leak" works productively and poetically. And even though Sandström's translations cannot be said to be strictly digital maneuvers, they can still be seen as results of both digital and artistic visualizations of the linguistic practice that has been explored both in scenic performances and on the research project's website. ${ }^{19}$ Together, these practices form a linguistic cabinet of curiosities in which the words, sounds and meanings are explored and shifted in an associative way, "a writing that in some way transcends," as Bernur writes (ibid.). So, we are back to the principle of pertinence again. To continue in line with Sandström's own puns, we can conclude that the province is not described with provenance.

In the language games and puns presented in works such as Across and The Hiss of History (represented also as digital performances on the project's website, as well as in the "dossier" The Coming Shall), both visual and acoustic aspects of the language are used as starting points for oscillatory and associative movements between the languages to be used and explored. Sandström can approach the language etymologically and lead us to the Greek roots of a word like "history." This, of course, is a traditional humanities approach, based on provenance; that is, origin and derivation. But the overall structure of the project coincides to a much greater extent

in Pater-Noster. MDCCXIX. See: http://www.pierre-marteau.com/editions/1719robinson-crusoe.html (accessed April 2020).

${ }^{19}$ Sandström's project has continually been updated on the website The Pages, http:// www.howeacrossreading.imrisandstrom.com/ (accessed April 2020). 
with the "dossier system," the principle of pertinence, since here, too, it is the object itself, not its origin, that establishes new, perhaps surprising, but not random relationships. This can happen if we take the language seriously, something that Sandström unceasingly demonstrates through her provocative direct translations, homophonic parallels, the unsettling of meaning and puns (which always have a serious undertone). We can describe it as an exploration of resonances, similarities and transcendences based on the principle of pertinence.

A congenial description of this principle can be found in one of the authors that Sandström (alongside Susan Howe) most often cites: Gertrude Stein. In "If I Told Him: A Completed Portrait of Picasso," we read the following lines:

Exact resemblance to exact resemblance the exact resemblance as exact as a resemblance, exactly as resembling, exactly resembling, exactly in resemblance exactly a resemblance, exactly and resemblance. For this is so. (Stein 1924)

History in Sandström's work resembles the word "Hiss," as in "a hissing," like the sound of the snake. Sandström cites the Webster dictionary which describes the sound of a human hissing thus: "To express contempt or disapprobation by hissing." But in The Hiss of History, of course, the most irritating "hiss" comes from the masculine subject ("his") who, purely semantically, not to mention actually, has been the dominating subject of history through the centuries. This, as we know, is an observation that has become something of a gender theory commonplace, but which in Sandström's work is thus twisted even further. And this subject is also found in Gertrude Stein's poem:

He he he he and he and he and and he and he and he and and as and as he and as he and he. He is and as he is, and as he is and he is, he is and as he and he and as he is and he and he and and he and he. (ibid.)

However, it is possible to add yet another twist to this (although Sandström does not mention it herself). Maybe we should change the word History, add the letter $\mathrm{T}$ and then get Thistory. Using the term Thistory instead of History would be congenial with what we might call a postmodernist credo: that each story told conceals another story. Thistory is always pregnant with Thatstory. Here again Gertrude Stein: "Let me recite what history teaches. History teaches." (ibid.) 


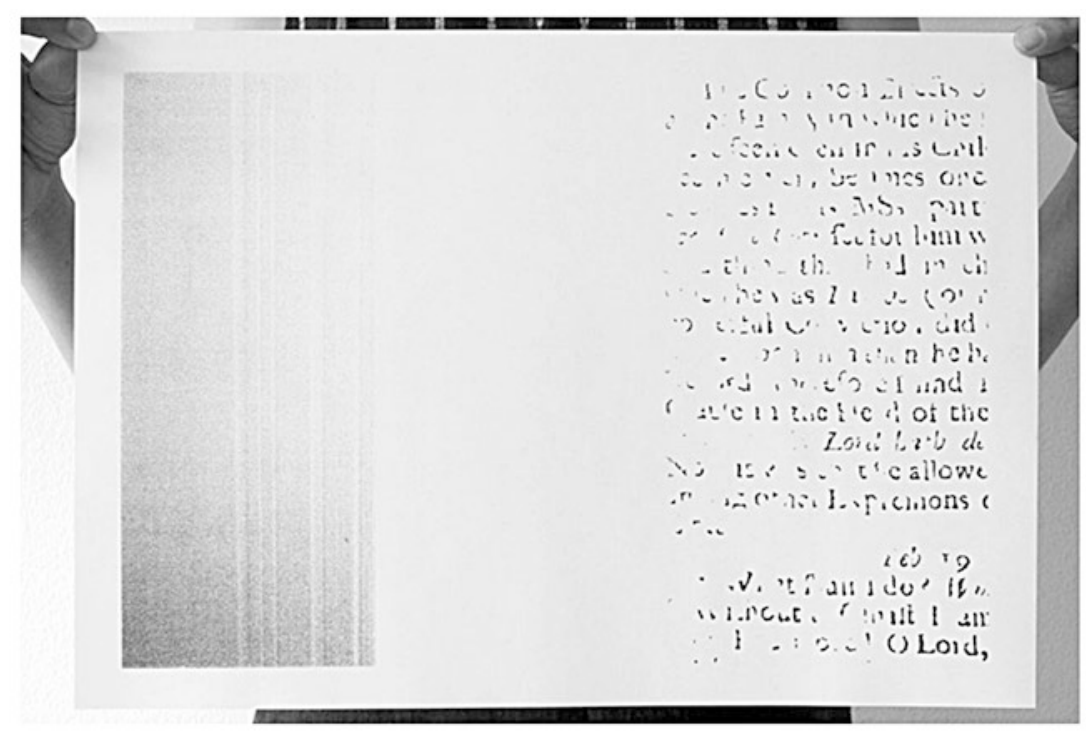

Fig. 3.2 Imri Sandström, from Flapping, Flapping, Flapping, Flapping (2014), screenshot ("This is a photograph of a risograph print of Flapping, Flapping, Flapping, Flapping, a digital image based on an excerpt from the Gale ECCO print on demand-version of a scanned version of Magnalia Christi Americana: or, the ecclesiastical history of New-England, from its first planting in the year 1620. unto the year of our Lord, 1698. In seven books. ... By ... Cotton Mather, ...”, quote from Flapping, Flapping, Flapping, Flapping)

The box, The Coming Shall (as well as the website), moreover contains the permutation O You Banner, Flapping, Flapping, Flapping, Flapping (Fig. 3.2), which can be seen as a media archaeological deconstruction of one of the Puritan priest and author Cotton Mather's books. Sandström describes the visual material of this project as based upon

a photograph of the lower corner of an entry in a print-on-demand version of a scanned version of Magnalia Christi Americana: or, the ecclesiastical history of New-England, from its first planting in the year 1620. to the year of our Lord, 1698. In seven books. ... By ... Cotton Mather ... (Sandström 2017, Oh You Banner, 4)

Sandström challenges and permutates this material through a variety of materializations (of a fragment of the scanned version of the page): as 
enlarged print; as a risograph print; as a textile flag; and, finally, as a flag trampled in blueberry rice, leaving bloodstain-like imprints. This is an emblematic work in many respects where the headline, visual elements and elaborate comments establish an oscillating relationship, to history, materiality, gender and moral appeal, which at the same time leaves much to the reader/viewer to extrapolate.

\subsection{KunstKammer Poetics}

Three small penguins, maybe 10-12 $\mathrm{cm}$ in height, standing on a small shelf. The note beneath them says: "The Basic Forms of Penguin Qi Gong or Settling Yourself in the Ice!" And there is a relatively long narrative displayed behind the penguins. It is a text about polar expeditions, penguins and Qi Gong. Apart from the observation (?) that penguins tend to stand in positions which mimic the positions in classic Qi Gong, the text does not make much sense. The list of references does not make much sense, either. All of them seem to be fake, except the one to the controversial psychoanalyst Wilhelm Reich's work on the Orgone. Whatever has that title to do with anything here?

Another item: "Two Parts of a Typewriter on Which Walter Benjamin Wrote His Famous Essay 'The Work of Art in the Age of Mechanical Reproduction'." The story told informs us that when in Dresden, to visit the dancer Mary Wigman, Benjamin continued the work on his famous essay, traveling with his portable typewriter. Unfortunately, the machine broke down, jammed, just at the letter "a" in the word "Kamera." When he obtained a new typewriter, the manuscript shows a change in typing style right at that word. Two fully recognizable references (Benjamin and Kittler) are here paired with two arguably (not to say obviously) fake ones. And even if we ignore the fact that Benjamin did not like typewriters and produced almost every manuscript in handwriting, this story of course is too good to be true.

The Museum der unerhörten Dinge (Museum of Unheard [of] Things) in Berlin, where these items are displayed, is really something special. The exhibition catalog describes the museum thus:

Museum der Unerhörten Dinge is

a "Literary Cabinet of Curiosities"

founded and curated by Roland Albrecht,

located between house numbers 5 and 6 
on Crellestraße in Schönenberg, Berlin

The museum displays unique things

and their unheard (of) stories,

all categorized according to weight,

and holds the record of being

the most visited museum in Berlin

(if one offsets the number of visitors

to the square meters of the exhibition space)

$\ldots$

It intends to grow as the museum collection expands.

At the present moment (Fall 2015) it contains 78 items. (Albrecht 2015, front matter)

I enter the museum with two friends. And suddenly the space seems full. It is that tiny. Yes, this museum contains fewer than 80 items, and the exhibition space may possibly be less than $25 \mathrm{~m}^{2}$. Yet, I spend hours in here. Why? As observed by Crane above, "the desirability of the curious object lay in its relation to a known or acceptable story." And this is precisely the story of this museum. The objects may seem irrelevant, or at best bizarre, but the narratives around them are so fascinating. And they confirm yet another of the criteria set out by Crane:

Curiosities belonged in a cabinet, where their unique stories retained them in each place; historical objects, however, derived their significance as much from their original site, or their collection site, as they did from an individual story. In this sense, the historical object participated in a narrative uniting location and experience, whereas the curiosity represented a transferable story. (Crane 2000, 76)

So, the object in a museum is exhibited to confirm the greater narrative, while the object in the KunstkammerCabinets of Curiosities is there for its own sake. Or for its relation to other objects rather than to the greater narrative. This is exactly what this Berlin Museum does. In what seems to be a further deconstruction of the notion that a museum should be contained in a unifying narrative, the exhibition catalog presents the objects in order of weight, from $1 \mathrm{~g}$ to $3800 \mathrm{~g}$. Or, to be precise, to 21,311 $\mathrm{g}$, which is the weight of the totality of the museum's objects.

The objects in themselves seem ordinary (a wedding photo, a bunch of screws), or maybe bizarre ("Film snippets of subfilms", "The Wasp Honeycomb Collection Point in Kröte"), but they do have this in 
common - the narratives attached to them are really captivating. And they blend fact and fiction without a blink. When Susan A. Crane visits David Wilson's Museum of Jurassic Technology in Los Angeles, she is struck by the same experience. And as a first comment on the "fake artifact" she quotes Samuel Johnson's reaction to Ossian manuscripts: "had it really been an ancient work, a true specimen [of] how men thought at the time, it would have been a curiosity of the first rate. As a modern production, it is nothing" (ibid., 64). Thinking about this harsh judgment of the fake artifact, Crane reflects on her experience at the Jurassic Museum of Technology and concludes:

To turn Johnson on his head: the value of curiosities is the opposite of that of antiquities. Rather than being "nothing," the modern curiosity is what curiosities have always been: a mixture of the natural and the artifactual (in the old sense of the word, meaning "man-made"), the historical and the ahistorical. ... Asking whether Jurassic technology is fact or fiction is beside the point. In the presence of museums, whether actual or represented, we still ask about veracity; to visit a curiosity cabinet, one must be prepared to be confounded. (ibid., 64-65)

This is a really productive feature of the epistemology of the Kunstkammer: that fake and veracity were not binary opposites in the narratives that constituted the totality of the collections. They were all parts of the wonders of the world (which indeed is another unifying narrative, but on a completely different scale than the ones prevalent in the museums that followed). It is also a strategy that may shed some deconstructive light on the notion of "fake news" so prevalent in the political discourse (and social media) of 2020. You may ask if it is problematic to mix fact and fiction as an artist or curator in this way, in the era of fake news? Or should we rather see it as a counter-strategy, to make us aware and observant, through the "shock" of confusion? Perhaps we could establish a genre, or type of texts and installations, that we label "Kunstkammer poetics," which without hesitation, and deliberately, mixes fact and fiction, in order to make us astonishingly aware?

To blend the authentic with the artificial is, of course, not a new feature of the digital age. The point here, though, is that the very same blend has different connotations in the age of digital communications than in the ages of romantic irony or avant-garde modernism. Another reason, rather than the historical moment, for a different reception of Kunstkammer 
poetics is that we easily can check the facts and call them fake. Thus the "confusion" may work as a pedagogical tool. And in terms of embodiment this strategy is interesting. To take the above example, I suddenly got very interested in the relation between Walter Benjamin and typewriters. I had to move myself, physically, from reading the text on the wall in the museum (or, to be honest, from the same text in the catalog) to my computer, browsing for "Benjamin" and "typewriter," or "Benjamin" and "manuscript." Just as with the emblem, the Kunstkammer poetics does not make me stay in the text; the solution, "the riddle," is not contained in the text, or the objects, alone, but in my embodiment of the text by my actions on the internet, and the agency this action invests me with.

Kunstkammer poetics. The 2018 Nobel Prize winner, Polish author Olga Tokarczuk, creates in her 2007 novel Flights (Bieguni, trans. 2017) a prismatic effect in her oscillating reflections on travel and movement (Tokarczuk 2017). The novel has no coherent narrative, but rather a handful of them, spanning from the seventeenth to the twenty-first century, and the novel is, as it turns out, a prime example of Kunstkammer poetics.

In the fragment "New Athens," the narrator concludes that no book becomes obsolete as quickly as the guidebook. ${ }^{20}$ But two of these s/he stills holds on to, albeit they are very old. The first is a Polish guidebook from the early eighteenth century, from which the text cites a long passage: "On other strange and wonderful persons of the world: That is Anacepholus, alias Headless, or Cynocephalus, alias Dog-Headed; and in other persons of curious form." What follows is indeed a page-long list of very curious, more or less human beings, which ends with the statement that every one of these creatures, as odd as he or she may be, inevitably is the descendant of Adam, and thus deserves salvation (ibid., 76-78).

In this fragment alone, Tokarczuk establishes several aspects of the cabinet of curiosities. The quote in itself, from the Polish priest Benedykt Chmielowski, is an obvious display of the bizarre wonders of the world, pure Kunstkammer prose, but Tokarczuk's fragment in itself establishes several juxtapositions. The end of the paragraph reads: "The other one is Melville's Moby Dick. //Though, if you can just check Wikipedia from time to time, that's also perfectly sufficient" (ibid., 78). So here the narrator suggests, as the second of two guidebooks, "written with real passion, and a genuine desire to portray the world," Melville's Moby-Dick—a novel

\footnotetext{
${ }^{20}$ I call the sections in Tokarczuk's novel "fragments," and this also bears witness to the intimate connections between Kunstkammer poetics and Romantic fragment aesthetics, a relationship worthy of future study.
} 
that in itself mix fact and fiction, statistics, archaic prose and sea adventures. ${ }^{21}$ The very recommendation to make complementary use of Wikipedia, moreover, emphasizes the bodily involvement in Kunstkammer poetics: move in and out of texts, check, get back, continue. Is this "The New Athens" addressed in the title of the fragment (Athens not mentioned otherwise)? Is Wikipedia- or Moby-Dick, or the cabinet of curiosities, or all of them - the new locus for education, maieutics and philosophy?

No coincidence, then, that the next fragment in Tokarczuk's novel is called "Wikipedia," where the narrator hails "mankind's most honest cognitive project," coming "straight out of our own heads, like Athena [!] out of Zeus's," and maybe "the greatest wonder of the world," since it "will hold everything" (ibid., 78). But then the narrator starts to question this:

After all what it has in it can only be what we can put into words - what we have words for. And in that sense, it wouldn't be able to hold everything at all.

We should have some other collection of knowledge, then, to balance that one out - its inverse, its inner lining, everything we don't know, all the things that can't be captured in any index, can't be handled by any search engine. For the vastness of these contents cannot be traversed from word to word - you have to step in between the words, into the unfathomable abysses between ideas. With every step we'll slip and fall.

It would appear the only option is to get in even deeper.

Matter and anti-matter.

Information and anti-information. (Ibid., 78-79)

So suddenly, Wikipedia, in all its wonder, needs to be supplemented by the void. This brings us back to the Museum of Unheard (of) Things and the introduction to the catalog, entitled "The Void and the Spontaneous Decay of the Vacuum or New Proofs of God," which begins thus:

The question of the void has occupied humankind since time immemorial and indeed concerns the question "where do I come from, where am I going?" It is the question about our existence, about the inescapable fact of death that plagues us. The void implies the question of being and thereby the question of space, for a void can only be conceived of spatially and a being fills up a space.

${ }^{21}$ And also, in 2010, being adapted as Fred Benenson's Emoji Dick; that is, Moby-Dick entirely narrated in emojis. 
The void is a place of nothingness, a place filled with nothingness. (Albrecht 2015, 2)

Why this occupation with nothingness when presenting a museum that contains 74 objects? Is it the void, the nothingness, that brings meaning to the objects in the Kunstkammer? Or is the quest for the dark matter in the universe: "It's a thing which we know exists, but without being able to access it, with any instruments" (Tokarczuk 2017, 233). Or is it the case that things we do not understand can only be reached by embracing the absurd, the fantastic, the curiosity? Tokarczuk's novel oscillates between the known and the absurd, and a recurring motif is the letters written by Josefine Soliman addressed to Emperor Francis I, begging him to return her father's body "stuffed and chemically treated - on view in the Cabinet of Natural Curiosities at the court of Your Majesty" (the father Angel being of African descent; ibid., 269). The void here seems to be the very body of poor Angel Soliman, and perhaps also the lack of any response from the royal highness. And moreover, a reminder of the not always pleasant objects on display in cabinets of curiosities.

Flights also displays an ongoing oscillation between stillness, as in the cabinets' exhibitions, and movement. As the title suggests, flights, like in airplanes, are recurring motifs in the novel, but also flights as in escape, running away-the Polish title Bieguni refers to a religious movement [sic!] who believed that being in constant motion would protect you from Satan, who most easily can strike us if we stand still. This constant mobility is treated ironically (or not?) when juxtaposed with twenty-first-century advertising:

At the airport, a big ad on a glass wall all-knowingly asserts:

Mobility is reality.

Let us stress that it is merely an ad for mobile phones. (Ibid., 234)

Significantly enough, this comes immediately before the fragment bearing the title of the novel, Flights. The Kunstkammer, the Museum der unerhörten Dinge and Tokarczuk's prose are joined in the appeal to make us see, to look anew on things around us. They present new optics. One final quote from Flights will illustrate this. In the lengthy fragment "Kunicki: Earth" - a story that is developed throughout the novel, about a man whose wife and child suddenly disappear and the only thing left is the contents of the woman's bags-Kunicki experiences some sort of epiphany: 
Suddenly he realizes: there are different kinds of looking. One kind of looking allows you to simply see objects, useful human things, honest and concrete, which you know right away how to use and what for. And then there's panoramic viewing, a more general view, thanks to which you notice links between objects, their network of reflections. Things cease to be things, the fact that they serve a purpose is insignificant, just a surface. Now they're signs, indicating something that isn't in the photographs, referring beyond the frames of the pictures. You have to really concentrate to be able to maintain that gaze, as its essence is a gift, grace. Kunicki's heart starts beating faster. (Ibid., 352-353)

Kunstkammer poetics, as suggested by the above examples, is characterized by its fragmented style, where every fragment somehow is selfsufficient, its own story, while it may or may not contribute to a unifying plot or narrative. Also it takes no shame in mixing fact and fiction, unsettling the reader's perception of what did actually happen, and also to make us aware, to beware. To trust and distrust, through associative play.

\subsection{Babbage. Again}

Let us summarize. Where our traditional interpretative traditions-despite the practice of "close reading"-have been established through distancing from the aesthetic experience, digital epistemology and Kunstkammer poetics encourage new sensations of presence. Rasmus Fleischer notes this too, in his postdigital manifesto:

The term postdigital does not signify a new cultural-historical stage, but rather a maturation of the digital experience that causes us to re-emphasize presence. ... To use yet another concept with the prefix "post" is justified only by the need to take action against the denial of events, presence, and coexistence that continue to characterize our era's discourse about digital culture. (Fleischer 2009, 43) 22 $^{22}$

There, in the insistence from digital epistemology on being close to us, we have an end point for this chapter, and a starting point for the chapters to come. However, since academic traditions—still—encourage the principle of circular composition, let us return to Göran Printz-Påhlson and Charles Babbage. We will read it again.

${ }^{22}$ On the concept of "presence," see Hans-Ulrich Gumbrecht (2004). 
And yes. There are several media archaeological and digital dimensions to reflect upon in this poem: the importance in programming to maintain "the greatest accuracy even in small things"; or the fact that the first "bug" in a computer was indeed not a dragonfly but close enough: a moth. But I will dwell upon the following.

The mathematician sits right next to Trinity College near the river Cam. Here, in one of the cradles of European educational culture, he reflects on existence (Printz-Påhlson 2011, 165). Something has been added. Vidocq - that trixter! — changed his own length. The larva came out of the pupa like a dragonfly. What is strange, though, is perhaps not the deviation, but that everything, almost always, follows the laws of mechanics and nature. But then, once in a while it happens: "the other number comes up" (remember Tokarczuk's longing for an encyclopedia containing "everything we don't know"; Tokarczuk 2017, 78).

Babbage is in Cambridge, but these thoughts he now reflects upon he has learned not in the lecture hall, nor in the library, but from his machine. Every day, more people are born than those who die. A sober statement, but in Babbage's monolog it adds a somewhat posthuman dimension: the dimension where one-sixteenth of a man has an intrinsic value, the upsetting of the rules of natural law, the transcendence of boundaries, the confirmation of the miracle. In and through the machine, Babbage sees this. In and through the digital, we observe this. Thus, let us never abandon reflection on history-through the machines.

\section{REFERENCES}

Albrecht, R. (2015). Museum of Unheard (of) Things, Exhibition Catalog (trans: Booth, A., \& You Nakai. Brooklyn). New York: Already Not Yet.

Andtbacka, R. (2008). Wunderkammer: Dikter. Helsingfors: Söderströms.

Bakhtin, M. (1981). The Dialogic Imagination: Four Essays Edited by Michael Holquist (trans: Emerson, C., \& Holquist, M.). Austin: University of Texas Press.

Benenson, F. (2010). Emoji Dick. By Herman Melville. Edited and compiled by Fred Benenson (trans: Amazon Mechanical Turk). Raleigh, N.C.: Lulu.

Bernur (Björn Kohlström's blog). (2018). Det kommande skallet/The Coming Shall, Imri Sandström, Autor. http://howsoftthisprisonis.blogspot. se/2018/03/det-kommande-skalletthe-coming-shall.html.AccessedApr2020. Bredekamp, H. (1995). The Lure of the Antiquity and the Cult of the Machine (trans. Brown, A.). Princeton N.J.: Marcus Wiener Publishers. 
Burroughs, W. S. (1962). The Invisible Generation. WUSTL Digital Gateway Image Collections \& Exhibitions. http://omeka.wustl.edu/omeka/items/ show/9535. Accessed Apr 2020.

Crane, S. A. (2000). Curious Cabinets and Imaginary Museums. In S. A. Crane (Ed.), Museums and Memory. Stanford, CA: Stanford University Press.

Fleischer, R. (2009). Det postdigitala manifestet. Stockholm: Ink förlag.

Gumbrecht, H. U. (2004). Production of Presence. What Meaning Cannot Convey. Stanford, CA: Stanford University Press.

Håkansson, G. (1997). Operation B. Stockholm: Bonnier.

Hansson, G. D. (1996). AB Neandertal. Stockholm: Bonnier.

Hansson, G. D. (2008). Olunn, Lunnebok, Idegransöarna (Mackerell, Book of Puffins, The Yew Islands), Compilation. Stockholm: Bonnier.

Hansson, G. D. (2009). "Över gränsen. Taxus o.a." (Crossing the Border. Taxus and Others). Unpublished manuscript, lecture.

Hejlskov Larsen, S. (1971). Systemdigtningen: modernismens tredje fase. København: Munksgaard.

Jönsson, J. (2012). med.bort.in. Stockholm: Bonnier.

Jönsson, J. (2014). Mot, vidare, mot. Stockholm: Bonnier.

Kelty, C. (2016). Participation. In B. Peters (Ed.), Digital Keywords: A Vocabulary of Information Society \& Culture. Princeton, NJ: Princeton University Press.

Latour, B. (1996). On Actor-Network Theory. A Few Clarifications Plus More Than and Few Complications. (Originally written in 1990, English version 1996). http://www.bruno-latour.fr/sites/default/files/P-67\%20ACTORNETWORK.pdf. Accessed Apr 2020.

Latour, B. (2005). Reassembling the Social. An Introduction to Actor-NetworkTheory. Oxford/New York: Oxford University Press.

Lindhé, C. (2013). 'A Visual Sense Is Born in the Fingertips': Towards a Digital Ekphrasis. Digital Humanities Quarterly, 7, nr 1. http://www.digitalhumanities.org/dhq/vol/7/1/000161/000161.html. Accessed Apr 2020.

Lotass, L. (2001). Aerodynamiska tal. Stockholm: Bonnier.

Lotass, L. (2007). Den vita jorden. Stockholm: Bonnier.

Lotass, L. (2011). Fjärrskrift. Stockholm: Drucksache.

Malmio, K. (2020). Du och jag, jag och du. Flerspråkighet, digitalisering och läsaren i Ralf Andtbackas Wunderkammer. Edda 03/2020.

Marks, L. (2002). Touch: Sensuous Theory and Multisensory Media. Minneapolis, MN: University of Minnesota Press.

Mauriès, P. (2015). Cabinets of Curiosities. London: Thames \& Hudson.

Önnerfors, A. (2017). På Pegasens vingar - den svenska idéhistoriens digitala epistemologi. Litteraturbanken. https://litteraturbanken.se/presentationer/specialomraden/Idehistorikern.html. Accessed Apr 2020.

Palm, G. (1964). Världen ser dig: Själensfurirochandra dikter. Stockholm: Norstedt.

Peters, B. (2016). Digital. In B. Peters (Ed.), Digital Keywords: A Vocabulary of Information Society o Culture. Princeton, NJ: Princeton University Press. 
Pirholt, M. (2010, October 14). Ralf Andtbacka - Wunderkammer. Dikter. Dixikon: mest om uländsk kultur och litteratur. https://www.dixikon.se/ralfandtbacka-wunderkammer-dikt/. Accessed Apr 2020.

Printz-Påhlson, G. (1966). Gradiva och andra dikter. Stockholm: Bonnier.

Printz-Påhlson, G. (2011). Letters of Blood and Other Works in English. Edited and trans Robert Achambeau. Cambridge, UK: Open Book Publishers.

Sandström, I. (2017). Det kommande skallet/The Coming Shall, Box with Booklets. Göteborg: Autor.

Sandström, I. (2019). Tvärsöver otysta tider/Across Unquiet Times. Dissertation. Göteborg: Autor.

Sandström, I. The Pages. Research Project Website. http://www.howeacrossreading.imrisandstrom.com/. Accessed Apr 2020.

Schrey, D. (2014). Analogue Nostalgia and the Aesthetics of Remediation. In K. Niemeyer (Ed.), Media and Nostalgia. London: Palgrave Macmillan.

Stein, G. (1924). If I Told Him: A Completed Portrait of Picasso. https://www. poetryfoundation.org/poems/55215/if-i-told-him-a-completed-portrait-ofpicasso. Accessed Apr 2020.

Sypher, W. (1968). Literature and Technology: The Alien Vision. New York: Random House.

Tokarczuk, O. (2017). Flights (trans: Croft, J.). London: Fitzcaraldo Editions.

Wiener, N. (1948). Cybernetics: or, Control and Communication in the Animal and the Machine. Cambridge, MA: MIT Press.

Open Access This chapter is licensed under the terms of the Creative Commons Attribution-NonCommercial-NoDerivatives 4.0 International License (http:// creativecommons.org/licenses/by-nc-nd/4.0/), which permits any noncommercial use, sharing, distribution and reproduction in any medium or format, as long as you give appropriate credit to the original author(s) and the source, provide a link to the Creative Commons licence and indicate if you modified the licensed material. You do not have permission under this licence to share adapted material derived from this chapter or parts of it.

The images or other third party material in this chapter are included in the chapter's Creative Commons licence, unless indicated otherwise in a credit line to the material. If material is not included in the chapter's Creative Commons licence and your intended use is not permitted by statutory regulation or exceeds the permitted use, you will need to obtain permission directly from the copyright holder. 